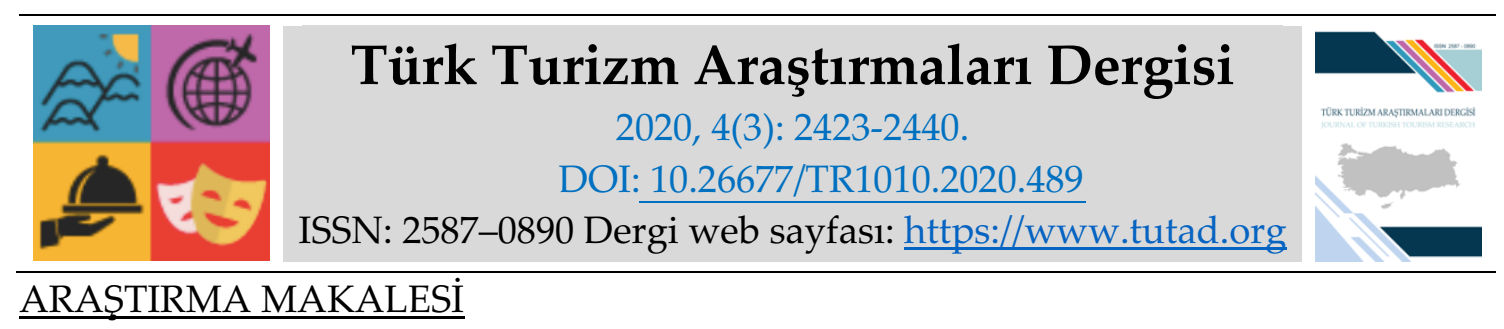

\title{
Konaklama İşletmelerinde Çalışan Yöneticilerin Yaratıcılık Engelleri
}

Dr. Öğr. Üyesi Hande Mutlu ÖZTÜRK, Pamukkale Üniversitesi, Turizm Fakültesi, Denizli, eposta: hmozturk@pau.edu.tr ORCID: https://orcid.org/0000-0002-4404-0106

Dr. Öğr. Üyesi Serap ALKAYA, Pamukkale Üniversitesi, Turizm Fakültesi, Denizli, e-posta: posta:salkaya@pau.edu.tr ORCID: https://orcid.org/0000-0002-0234-6692

Öz

Yapılan bu araştırmanın amacı, otel işletmelerinde çalışan yöneticilerin yaratıcılıklarının önündeki engellerin belirlenmesidir. Araştırmanın evrenini, Pamukkale Üniversitesi'nde 9 Mart 2020 tarihinde dördüncüsü gerçekleşen Kariyer günleri'ne 43 otelden katılım gösteren yöneticiler oluşturmaktadır. Araştırma kapsamında veriler anket yöntemi ile toplanmıştır. Elde edilen tüm veriler İstatistik paket programında frekans analizi, faktör analizi, korelasyon analizi, Kolmogorov-Simirnov testi, Mann-Whitney U testi ve Kruskal-Wallis testi kullanılarak analiz edilmiştir. Araştırma sonucunda, katılımcıların çalıştıkları kurumlarda çok fazla değişim korkusu yaşamadıkları, eleştiri almadıkları, zaman ve iş baskısına maruz kalmadıkları, örgüte ve sisteme bağlılıklarının yüksek olduğu ve çalıştıkları kurumdaki kuralları ve şirket tarzını katı bulmadıkları tespit edilmiştir. Yapılan Kruskal-Wallis Testi sonucunda yöneticilerin eğitimleri ve mevcut iş yerindeki çalışma süreleri ile katı kurallar ve şirket tarzı arasında anlamlı bir farklılık olduğu tespit edilirken; Mann-Whitney U testi sonucunda ise cinsiyet ile katı kurallar ve şirket tarzı arasında anlamlı bir farklılık olduğu tespit edilmiştir. Çalışma sonucunda lisansüstü düzeyde eğitim alan yöneticilerin katı kurallar ve şirket tarzını lise, ön lisans ve lisans mezunu yöneticilere göre daha fazla yaratıcılığa engel olarak gördüğü sonucuna ulaşılmıştır. Ayrıca, erkek yöneticilerin, katı kurallar ve şirket tarzını $(\mathrm{p}=0,016<0,05)$ kadın yöneticilere göre daha fazla yaratıcllı̆̆a engel olarak gördüğü tespit edilmiştir.

Anahtar Kelimeler: Yaratıcılık, Yaratıcılık Engelleri, Yönetici, Konaklama İşletmeleri.

Makale Gönderme Tarihi: 14.04 .2020

Makale Kabul Tarihi: 07.07.2020

\section{Önerilen Atıf:}

Öztürk, H. M. ve Alkaya, S. (2020). Konaklama İşletmelerinde Çalışan Yöneticilerin Yaratıcılık Engelleri, Türk Turizm Araştırmaları Dergisi, 4(3): 2423-2440.

(C) 2020 Türk Turizm Araştırmaları Dergisi. 


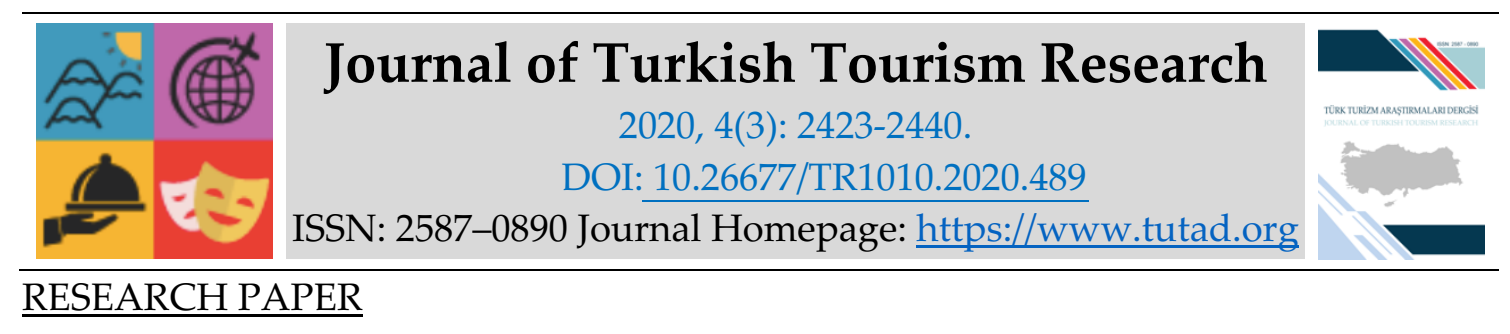

\title{
Creativity Barriers of Managers Working in Hospitality Industry
}

Assistant Prof. Dr. Hande Mutlu ÖZTÜRK, Pamukkale University, Tourism Faculty, Denizli, email: hmozturk@pau.edu.tr ORCID: https://orcid.org/0000-0002-4404-0106

Assistant Prof. Dr. Serap ALKAYA, Pamukkale University, Tourism Faculty, Denizli, e-mail: posta:salkaya@pau.edu.tr ORCID: https://orcid.org/0000-0002-0234-6692

\begin{abstract}
The purpose of this research is to identify the barriers to the creativity of the managers working in hotel businesses. The universe of the research is comprised of managers from 43 hotels attending the fourth Career Days which took place on March 9, 2020 at Pamukkale University. Within the scope of the research, the data were collected using the survey method. All the data obtained were analyzed in the Statistical package program using frequency analysis, factor analysis, correlation analysis, Kolmogorov-Simirnov test, Mann-Whitney U test and KruskalWallis test. As a result of the research, it has been determined that the participants do not have too much fear of change in the companies they work in, they are not criticized, they do not experience time and work pressure, they have high commitment to the organization and the system and they do not find the rules and company style rigid in the companies they work in. As a result of the kruskal-wallis test, it was determined that there was a significant difference between the training of the managers and the working times at the current workplace, and rigid rules and company style; As a result of the mann-whitney $u$ test, there was a significant difference between gender and rigid rules and company style. As a result of the study, it was concluded that the managers who received postgraduate education see the strict rules and company style as an obstacle to creativity compared to high school, associate and undergraduate graduate managers. In addition, it has been found that male managers see strict rules and company style $(p=0.016<0.05)$ as a barrier to more creativity than female managers.
\end{abstract}

Keywords: Creativity, Creativity Barriers, Manager, Accommodation Businesses.

Received: 14.04 .2020

Accepted: 07.07.2020

\section{Suggested Citation:}

Öztürk, H. M. and Alkaya, S. (2020). Creativity Barriers of Managers Working in Hospitality Industry, Journal of Turkish Tourism Research, 4(3): 2423-2440.

(c) 2020 Türk Turizm Araştırmaları Dergisi. 


\section{Gíriş}

İnsan günlük yaşamında birçok alanda karşılaştığı sorunlara çözüm üretmeye çalışmış ve bunun için yaratıcılığını kullanmıştır. Yaratıcılık, eğitim, psikoloji, sosyoloji, sanat, mimarlık, mühendislik gibi farklı alanlarda birçok bilim insanının uzun süredir üzerinde önemle durduğu bir konudur. Günümüzde yaratıcılık hala araştırılan yönleriyle önemli bir unsur haline gelmiştir. Bunun nedeni, yaşam koşullarındaki değişiklikler, sanayi ve teknolojide yaşanan hızlı değişimlerin kişilerin günlük ve iş yaşamlarında bu değişime uyum sağlamalarını gerektirmiş olmasıdır. Bu da gerek insanlara gerekse işletmelere yaratıcılık unsurlarını günlük hayatta etkili bir şekilde kullanmayı gerektirmektedir. İşletmeler sorun çözümünde yaratıcı fikirlere ihtiyaç duymaktadır.

Samen (2008) yaptığı çalışmada yaratıcı olarak nitelendirilen işletmelerin diğer işletmelere göre avantajlarından bahsetmiştir. Buna göre yaratıcı işletmeler; kıt kaynaklarını daha iyi değerlendirebilen, yeni ürün ve hizmetler geliştiren işletmelerdir. Ayrıca bu avantaj işletmelere rakipleri arasında farkedilebilir olmayı sağlayabilmektedir. Samen'e (2008) göre yaratıcılı̆̆ın gelişmesi için bir işletmedeki iklim çok önemlidir ve bu durum tamamen insan faktörüne bağlıdır.

Yaratıcı düşünme ve problem çözme eylemi ancak rahat, zaman baskısında uzak bir ortamlar sağlandığında gerçekleşebilir. Yaratıcılık değişen dünyada her işletmenin rekabet ortamında varlığını sürdürmek için sahip olması gereken en önemli özelliklerden biridir. Bir kısmı doğuştan gelen, düzeyi kişiden kişiye değişkenlik gösterebilen yaratıcılık potansiyeli herkeste vardır ancak istenirse geliştirilebilir. Bazı durumlarda ise engellenebilmektedir. Yaratıcılık en basit anlamda yenilik yaratma, bilinmeyeni ortaya çıkarma ve keşfetme anlamında kullanılır. Yaratıcılık kavramına farklı bakış açıları vardır. Bu perspektiflerde, bazen süreç, bazen ürün ve bazen de bir tür kişilik yapısı vurgulanmaktadır. Ancak, tüm bu farklı bakış açılarının ortak görüşü, yaratıılığın yenilikleri ortaya çıkarmasıdır (Boz ve Öztürk, 2020).

\section{KAVRAMSAL ÇERÇEVE}

Çağımızda yaratıcılık, çeşitli alanlarda çok büyük bir öneme sahiptir ve bireylerin psikolojinin sınırlarını aşma yeteneği nedeniyle, sosyal ve beşeri bilimler tarafından ele alınan konulardan birisidir. Popescu ve diğerleri (2015), okul öncesi çocuklarda yaratıcılığın gelişimi üzerine bir çalışma yaparak, sonuçlarını aile ile ilişkilendirerek rapor etmişlerdir. Yapılan çalışmada; ebeveynlerin davranış ve tarzlarının çocuklarda yaratıcılık üzerine etkisini ölçmek için bir model kurarak, yaratıcılık endeksi ve ebeveynlerin çocuklara karşı tutumu arasında bir ilişki belirleyerek, ebeveynlik tarzının çocukların yaratıcılık düzeyleri üzerindeki etkisini araştırmışlardır. Çalışmanın sonucunda, ebeveynleri kendilerine karşı olumlu bir tutum sergileyen çocukların yaratıcılık indeksi yüksek olduğu görülmüştür. Ebeveynlik tarzlarının etkisi ile ilgili olarak, araştırmanın sonucunda şu bulgulara ulaşılmıştır; otoriter ebeveynlerin çocuklarında düşük yaratıcılık düzeyleri görülürken, çocukları ile işbirliği kuran ebeveynlerin çocuklarının yaratıcılıklarının yüksek olduğu görülmüştür. Çocuklarda uyumlu ve yaratıcı bir gelişme için, çocukların katı kurallar olmadan uyarıcı bir ortama ihtiyacı olduğu, sakin ve güven ortamlarda büyüyen çocukların daha yaratıcı oldukları sonucuna varılmıştır. Çalışmada, etnik köken, sosyal arka plan ve hatta öğretmenlerin veya ebeveynlerin kişilik özelliklerinin etkilerinin detaylı olarak incelenmesi gerektiğine de vurgu yapılmıştır. Sternberg, (2005) yaptığı çalışmada hem yaratıcılığı engelleyen engelleri hem de yaratıcılı̆̆ uyaran destekleyici faktörleri analiz etmenin gerektiği üzerinde durmuştur. Sternberg (2005)'e göre yaratıcılık yolundaki herhangi bir engel, yaratıcı yeteneklerin optimal koşullar altında mümkün olan tam potansiyellerini 
geliştirmesini de engellemektedir. Popescu ve diğerleri (2015) de yaratıcılığın önündeki en büyük engelin, çocukta girişimciliği engelleyen ve yüksek bir kontrol seviyesi ile karakterize edilen otoriter ebeveynlik tarzı olduğunu belirtmektedir.

Boz ve Öztürk (2020) yaptıkları çalışmada genel olarak yaratıcılık fikrini ve turizim sektöründe yaratıcılığın önemini tartışmışlardır. Yaptıkları çalışmada gastronomi öğrencilerinin yaratıcılık düzeylerini etkileyen parametrelerin ölçülmesi konusunda bir anket çalışması ve sonuçlarını paylaşmışlardır.

Yapılan bir diğer çalışmada öğretim elemanlarının ve öğrencilerin algılarını inceleyerek mühendislik eğitiminde "yaratıcılık" üzerine çalışılmış ve yaratıcı bir çevreyi engelleyen faktörler (yaratıcılık engelleyicileri) tanımlanmaya çalışılmıştır. Çalışma, yaratıcılığa elverişli bir eğitim ortamı yaratan faktörleri belirlemek için psikoloji ve eğitim psikolojisi alanlarındaki yerleşik araştırmaların gözden geçirilerek, bu faktörlerin, öğrencilerde yaratıcılığı geliştirmeye elverişli bir eğitim ortamı oluşturan bir dizi kriter olan "Eğitimde Yaratıcılığın On Maksimi" olarak ifade edilmiştir (Foley ve Kazerounian, 2007).

Yaratıcılığın önündeki engellerin ve yaratıcılığı teşvik eden tutumların mevcut tartışması, geniş bir yaratıcılık anlayışına dayanmaktadır. Bazı akademisyenler herkesin yaratıcı olarak doğduğunu, ancak evde, okulda ve toplumdaki sosyal baskıların ilk yıllarının canlı hayal gücünü yok ettiğini ve uyumu teşvik ettiğini savunuyorlar. Aşağıdaki beş engel kategorisi - öğrenme ve alışkanlık, kurallar ve gelenekler, algısal engeller, kültürel engeller ve duygusal engeller - farklı ama örtüşen kategorilerdeki yaratıcılık bloklarını ayırt etmeye yardımcı olacaktır (Davis, 1999).

İşletmelerde yaratıcıllğ̆ etkileyen çeşitli faktörler vardır. Bunlar; yönetsel, örgütsel, toplumsal ve bireysel faktörlerdir (Samen, 2008). Yaratıcılığı destekleyen ya da engelleyen birçok parametre vardir.

Khalilinezhad ve diğerleri (2017) günümüzde öğrenci yaratıcıllğının ortaya çıkarılabilmesi için eğitimin en önemli amaçlarından birisi olduğuna vurgu yaparak, yaratıcılık engellerini tanımlamış, bu engelleri kaldırmak ve öğrencilerin matematikteki öğrenme ve yaratıcılıklarının gelişmesi önündeki etkileri araştırmıştır. Bu araştırmada, denekler kontrol ve deneysel olmak üzere iki homojen gruba ayrılmış ve deney grubunu eğitmek için yaratıcılık engelleri kaldırılmış ve öğrenme, yaratıcılık ve öğrencilerin matematiğe olan ilgileri incelenmiştir. Daha sonra tanımlayıcı ve çıkarımsal istatistiklerle elde edilen bilgiler analiz edilmiştir. Bağımsız ve eşleştirilmiş numuneler için T-testi sonuçları, yaratıcılık engellerini kaldırmanın matematikte öğrencilerin öğrenme ve yaratıcılıklarını olumlu yönde etkileyeceğini göstermiştir. Khalilinezhad ve diğerlerine (2017) göre yaratıcılık ülkelerin büyümesi, gelişmesi ve ilerlemesinde önemli ve belirleyici bir faktör olarak kabul edilmektedir. Bunun nedeni, yaratıcılığın bireylerin büyümesine ve yeteneklerinin gelişmesine ve kendini gerçekleştirmesine yol açabilmesidir. Çevresel koşullar, ortaya çıkan yaratıcılıkta çok önemli bir rol oynamaktadır ve yaratıcılık engellerinden yoksun bir ortam, öğrencilerin öğrenmesini artırabilmektedir.

Ancak yaratıcı düşünce önünde her zaman, insanların bu tür engellerden haberdar olmamaları veya buna dikkat etmemeleri nedeniyle bazı engeller vardır ve bu durum da başarısızlığa neden olabilmektedir. Ayrıca, sadece engellerin varlığı yaratıcı düşüncenin ortaya çıkmasını önünde engel olmayabilir. İnsanların yaratıcılık yönlerinin teşvik edilmesi, yaratıcı fikirlerin ortaya çımasını sağlar ve bu tür organizasyonlar her gün daha yenilikçi ve inovatif olabilirler (Ghafarian Shirazi, 2014). Nordin ve Malik (2015)'e göre yaratıcılık; kişilik, çevre, bulunduğu durum, motivasyon, bilişsel gelişim ve hatta duygusal, algılama, kültürel, çevresel birçok farklı engelden etkilenebilir. Bu engeller, yaratıcılık becerilerinin performansını engelleyebilecek bloklar gibidir. Yaratıcllık olmadan, bir kişi mevcut bilgi ve kaynakların çok iyi kullanamaz, 
bunun yerine eski alışkanlıklara, yapılara, örüntülere, kavramlara ve algılara kilitlenir. Rinkevich (2011) yaratıcıllı̆ın başarının bir belirleyicisi olduğunu ancak, öğretmenin yaratıcılık görüşüne bağlı olarak sınıftan sınıfa değişebileceğini vurgulamıştır. Bu nedenle bir öğretmenin bakış açısı, yaratıcı öğretime olası bir engel de oluşturabilir. Belirli durumlarda, öğretmen özellikleri ve okulun yapısı yaratıcılı̆̆ı olumsuz yönde etkileyebildiği gibi bazı durumlarda olumu etkileyebilir. Rinkevich (2011)'e göre yaratıcı öğretim için özerklik gereklidir. Ahmadi ve diğerleri (2014) yaratıcılığın önündeki engellerin nasıl ortadan kaldırılabileceğini tartışmışır ve yaratıcılığın önündeki engellerin insanların yaratıcılık potansiyelini ortaya koymasını engelleyebildiğini belirtmiştir. Yaratıcılı̆̆ın önündeki bu engellerin farkındalığı, kişileri engelleri tanımaya ve engellerden kaçınmaya hazırlayabilir.

Kazerounian ve Foley (2007) yaptıkları bir çalışmada öğretim elemanlarının ve öğrencilerin algılarını inceleyerek mühendislik eğitiminde "yaratıcılık" kavramını incelemişlerdir. Yaratıcı bir ortamı engelleyen faktörleri (yaratıcılık engelleyicileri) tanımlamayarak, yaratıcılığa elverişli bir eğitim ortamı yaratan faktörleri belirlemek için psikoloji ve eğitim psikolojisi alanlarındaki yerleşik araştırmaları gözden geçirmiş̧lerdir. Çağdaş mühendislik eğitiminde, eğitimcilerin ve öğrencilerin algılarını inceleyerek, mühendislik dışı eğitimcileri ve öğrencileri de kapsayan anketler tasarlamışlardır. Çalışmada, mevcut mühendislik öğrencilerinin akademik deneyimlerinin bir parçası olarak yaratıcı olmadıkları gözlemlenmiştir. Problem çözmeye odaklanan mühendislik öğrencileri, bir problemi izlerken açık fikirli olmadıkları ve bunun da yaratıcılığı engellediği ifade edilmiştir. Yenilikçi bir problem çözme süreci için gerekli olsa da, mühendislik eğitiminde öğrencilere açık fikirli olmanın öğretilmediği sonucuna varılmıştır. Kazerounian ve Foley (2007) tarafından yapılan çalışma yaratıcılık engelinin üniversite eğimi ile oluşabileceği konusunda ipuçları vermektedir.

Gonçalves (2017) yaratıcılığın, sürekli değişen bir dünyada yeniliği körüklediğinden, tasarım fikrinin de özünde yer aldığını ifade etmektedir. Yaptığı çalışmasında tasarımcıların yaratıcılığının önündeki engelleri incelemiştir. Gonçalves (2017) bazı durumlarda tasarımcılar genellikle kendi çözümlerinde, örneklerde veya tasarım sürecinde sıkışıp kaldığını belirtmiştir. Çalışma kapsamında tecrübesiz tasarımclar üzerinde yapılan çalışmada bir fikre bağlanma ve yaratıcılığın diğer engelleri ile başa çıkma stratejilerini görebilmek için görüşmeler yapılmıştır. Tasarımcıların bir fikre bağlanmasının yaratıcılığı sınırladığını göstermektedir. Ayrıca, çalışma tasarımcların mevcut düşüncelerine devam etmek için uyguladıkları fırsatçı ve bazen beklenmedik stratejileri ortaya koyduklarını göstermiştir. Benzer olarak Agogué ve diğerleri (2014) ve Cardoso ve Badke-Schaub (2011) de bir fikre bağlanmanın etkilerini incelemiş ve bunun yaratıcı çözümlerin üretilmesini engelleyebilecek bir takım engellerle oluşturabileceğini ifade etmiştir.

Stobbeleir ve diğerleri (2010) tarafından yapılan çalışmada ise çalışanların yaratıcılığını kolaylaştıran bireysel ve bağlamsal faktörlerin belirlenmesi amaçlanmıştır. Literatürde çalışanların yaratıcılığı için kritik faktörlere ilişkin çelişkili araştırma sonuçları da bulunmaktadır. $\mathrm{Bu}$ çelişkilerin temelinde, yaratıcılığın belirli alt süreçleri üzerindeki potansiyel farklılıkların etkisinin araştırılmasına verilen dikkat eksikliği vardır. Tarihsel olarak, bilim insanları yaratıcılıkla ilgili yaptıkları çalışmalarda sonuca odaklanmışlardır, ancak bu faktörlerin yaratıcı süreçteki çeşitli aşamaları nasıl farklı şekillerde etkilediği hakkında çok az şey bilinmektedir. Bu nedenle Stobbeleir ve diğerleri (2010) çalışmalarında önceki çalışmalarda yaratıcllı̆̆n önemli belirleyicileri olarak tanımlanan yaratıcı sürelerin beş aşaması üzerinde olası farklı etkisini araştırmıştır: (1) kişilik; (2) ödüller; (3) iş arkadaşlarının rolü; (4) liderlik; ve (5) iş ortamının yapılandırılması. Stobbeleir ve diğerleri (2010) yaratıcı sürecin bir aşamasında ortaya çıkan faktörlerin, diğer aşamalarda gözlenen faktörlerle aynı olmadığını ifade etmektedirler. Aslında, bir aşamada yaratıcılığın önkoşulları bazen başka bir aşamada yaratıcılık için gerekli koşullarla 
çelişebilir. Yaratıcılığa olan ilginin artması, birçok kuruluşun odaklanmayı üretimden bilgi çalışmalarına kaydırması ve dolayısıyla çalışanlarının rekabet avantajı oluşturma ve sürdürme konusundaki yaratıcılıklarına giderek daha fazla bağımlı olmalarından kaynaklanmaktadır.

McCrae ve Costa (1997) yaratıcılığa başka bir açıdan bakarak, çalışanın yaratıcılığının çalışanın bireyselliğinin, çalışanı çevreleyen bağlamın özelliklerinin ve ikisi arasındaki etkileşimin bir işlevi olduğunu ifade etmektedirler. Yani, bireysel farklılıklarla ilgili olarak, eğer yaratıcı birey bilgiyi alma konusunda esnek ise yaratıcı sonuçların ortaya çıkma olasılığı çok daha yüksek olmaktadır. O nedenle yaratıcılık eğer geliştirilmek isteniyor ise yaratıcılık önündeki engeller kaldırılmalı ve bireyler özgürleştirilmelidir. Diğer birçok araştırmacı da yöneticilerin ve kuruluşların yaratıcılık çalışma hedefleri belirlemesi gerektiğini ve çalışanların yaratıcılığını destekleyen çalışma ortamları yaratıldığında yaratıcı hedeflere ulaşılabileceğine işaret etmişlerdir (Amabile ve Mueller, 2008; Paulus, 2008; Tierney, 2008; West ve Richter, 2008).

Lee ve diğerlerine (2019) göre şirket performansının önemli itici güçleri arasında yaratıcılık ve yenilik gelmektedir. Yaptıkları çalışmada, restoran sektöründe pazarlama, yönetim, süreçler ve hizmetlerde yaratıcılığa ve yeniliklere çok az önem verildiğini, ağırlıklı olarak "mutfak" yeniliklerine odaklanıldığını işaret etmektedirler. Çalışmalarında, yaratıı fikirler, farklı yenilik türleri ve bunların uygulanmasındaki engeller üzerine odaklanmışlardır. Çalışmada, restoran girişimcilerinin hizmet, süreç, pazarlama, yönetim ve ürünlerdeki yenilikleri nasıl başlattığı, geliştirdiği ve uyguladığı hakkında yeni bilgiler sunmuşlardır. Lee ve diğerleri (2019) Avustralya'daki restoran sahipleri ile yapılan görüşmelerden elde ettikleri ampirik verileri inceleyerek restoran girişimcilerinin; önde gelen rakiplerin uygulamaların taklit ettiklerini, medya kaynaklarını tarayarak yeni fikirler üretmeye çalıştıklarını ve müşteri geri bildirimlerini analiz ederek yeni fikirler ürettiğini ortaya koymuşlardır. Araştırma sonuçlarına göre, bu sektörde pazarlama yenilikleri en çok geliştirilen yenilik türü olurken, yönetim sistemi yenilikleri ise en az üzerinde durulan konu olmuştur. Bulguları, fikir üretme ve yeniliğin uygulanmasındaki yaratıcılığın iki ana zorlukla sınırlı kaldığını göstermektedir; değişime karşı direnç ve yeniliklerin müşteri tarafından kabul edilmeme korkusu. Bu bulgular, yaratıcı fikirlerin hayata geçirilememesinin önündeki engellerden birisinin de korkular ve şüpheler olduğunu ortaya koymaktadır. Rosenbusch ve diğerleri (2011) de işletme sahiplerinin restoran içinde girişimci bir kültür yaratma gereğini bildiklerini, çünkü bunun firmanın performansına olumlu bir etkisi olabileceğini düşündüklerini ancak buna rağmen, inovasyon ve değişimin önündeki en büyük engelin de çoğunlukla içeriden kaynaklandığını ifade etmektedirler.

Fazelian ve Azimi (2013) ifadeleri ile yaratıcılık ve yaratıcılı̆̆ın önemi hakkında çoğunlukla görüş birliği olsa da, yaratıcı insanın ulusal, uluslararası ve küresel düzeyde engelleri olduğunu vurgulamışlardır. Araştırma sonuçlarına göre, yaratıcı bir kişi bireysel ve sosyal engellerle birlikte siyasi, kültürel ve ekonomik engellerle karşılaşabilmektedir. Fazelian ve Azimi (2013) yaratıcılığın önündeki engelleri üç bölüme ayırmıştır; kültürel engeller, çevresel engeller ve kişisel engeller. Fazelian ve Azimi (2013) bu engelleri şu şekilde tanımlamışlardır: Sosyal çevre şüphesiz birey üzerinde önemli bir etkidir veya yaratıcılığının oluşumunu önleyebilmektir. Bir kişi, yeteneğine inanılmadığı bir ortamda büyüyorsa, yeni ve yenilikçi bir ürün ortaya çıkarmaya çalışmayacaktır. Başkalarının sosyal davranışını taklit eden bireyler, kendisine karşı davranışları tarayacak ve bireysel yaratıcılığın gelişmesi veya engellenmesi yönünde bir davranış geliştirecektir. Kültür erken çocukluk evresinden başlayarak bir davranış geliştirmesine zemin hazırlayacaktır. Çocuk üzerindeki baskılar genellikle çocuğun davranışını mümkün olan en kısa sürede terk etmeye ve bir yetişkin gibi davranmaya itecektir. Bu nedenle, birçok oyun, uygulama, hikaye, şiir, kurgu ve çocuğun ya yaratıı dünyasını geliştirir veya köreltir. Diğer yandan okulun en başından beri öğretmenler ve eğitmenler, öğrencilere yetenekler kazandırmaya ve akademik bilgiler vermeye çalışıyorlar. Ebeveynlerin ve sınıf arkadaşlarının beklentileri, çocuğun 
büyümesine yönelik yetenek ve yetenek düzeyleri, aldığı eğitim ve öğretim öğrencilerin kişiliklerinin gelişimini etkilediği gibi yaratıcılıkları üzerinde de rol oynarlar.

Azimi (2012) yaratıcı insanların da anlayışlı olduklarını ve genellikle farklı düşündüklerini, belirli uzmanlık alanı ve yaratıcı çabaya derin bağlılık hakkında geniş bilgiye sahip olduklarına vurgu yapmaktadır. Yaratıcı kişiler esnek düşünürler, yeni durumlar ararlar ve birçok olasılık hayal ederler. Ancak Azimi (2012)'ye göre büyüme ortamı ve refah düzeyi, okudukları okul, büyüdükleri çevre, sahip oldukları kültürel bazı durumlarda yaratıcılığın önünde yaratıcıllğın engeli de olabilmektedir.

Buradan şu sonuca da varılabilir; yaratıcılık anla ilgili değildir. Yaratıcılığın geçmişle bağları vardır. Bu bağlar bazen yaratıcılığı besler ve ortaya çıkmasını sağlar, bazı durumlarda ise yaratıcılığın önünde bir engel olarak belirir. Diğer yandan yaratıcıllı̆̆ın geliştirilmesi için kurumsal bir yaklaşım da şarttır. Kurumsal olarak yaratıcılığın gelişmesi için fiziksel veya sosyal ortamlar yaratılabilir ve bunun tersi de doğrudur. Kurumsal bir yaklaşım geliştirilemez ve bireylerin özgür düşüncelerini ifade edebilmelerine olanak sağlanamaz ise, yaratıcılık sağlanamayabilir. Dolayısı ile yaratıcılığın önündeki en büyük engellerden birisinin de kurumların çalışanlara bakış açıları ve kurumsal yapılar olduğu söylenebilir.

El-Masry ve Mostafa'nın (2008) pazarlama yöneticileriyle ilgili yaptığı çalışmasında, Mısırlı ve İngiliz yöneticilerin yaratıcılığın önündeki örgütsel engellerle ilgili tutumlarında nasıl farklılıklar olduğunu ortaya koymuştur. Çalışmada iki toplum arasındaki örgütsel yaratıcılığın önündeki algılanan engellerdeki farklılıkları incelemek için 17 maddelik Yaratıcılık Önündeki Engeller ölçütü kullanılmıştır. Bu maddelerle ölçülen engeller arasında riskten kaçınma, başarısızlık korkusu, zaman baskısı ve yönetimin önerileri reddetmesi gibi faktörler bulunmaktadır. Toplam sonuçlar, 17 maddenin 16'sında önemli farklılıklar olduğunu ortaya koymuştur. El-Masry ve Mostafa (2008), temelde yatan bazı kültürel farklılıkların, özellikle de Batı kültürlerinin, Mısır toplumunda bulunan kolektivist yönelime karşı bireyselci doğasının bulgularını nasıl açıklayabileceğine dair açıklamalar sunmuşlardır. Bu farklılıklar göz önüne alındığında, yaratıcılıkla ilgili yönetim uygulamalarının kültüre göre değiştiği fikrini ortaya atmışlardır. Özgürlük, öz-yönelimli karar verme ve sonuca genel bir odaklanma Batı kültürlerinde faydalı olurken, Arap kültürlerinin yüksek güce sahip yöneticilerin, özellikle bir ekibin bir göreve nasıl yaklaşması gerektiği ve uygulanması gereken stratejiler konusunda daha fazla müdahil olmasına sebep olmaktadır. Dolayısı ile kültürel farklılıklar, iş yapış biçimleri ve organizasyon yapıları toplumdan topluma değiştiğinden yaratıcılık düzeyleri ve ifade etme şekilleri de toplumdan topluma değişmektedir.

Walter (2012) çalışanların çalışmalarına yaratıcı bir şekilde yaklaşmalarını sağlama yeteneğine sahip olmayan kuruluşların, kuruluşun yenilikçi çıktısını sınırlayacağını ve rakiplerinin gerisinde kalabileceğine vurgu yaparak, Tayland merkezli bir Avrupa teknoloji şirketinin şubesinin çalışma ortamındaki yaratıcılığın önündeki engelleri belirlemek için bir çalışma yürütmüştür. Yapılan çalışmada yaratıcı çıktıyı azaltabilecek çalışma faktörleri bileşen teorisi kullanılarak çıkarılmış; kültürel ve fiziksel çalışma ortamı analiz edilmiştir. Yapılan çalışmanın sonuçları, diğer çalışmalara benzer olarak yaratıcılığın önündeki ana engellerin risk alma korkusu, fiziksel çalışma ortamı, zaman baskısı, özerklik ya da özgürlük, kontrol ve iç çatışma risk algısı biçimindeki örgütsel engeller olarak özetlenmiştir.

Birçok çalışmada yaratıcılık farklı açılardan ele alınmıştır. Yaratıcılığın önündeki engellerin irdelenmesi bu süreci değiştirmede etkili olabilir. Bu alanda yapılan çalışmaların birçoğu yaratıcılığın kendisini doğradan ele almaktadır. Bu çalışmada yaratılık engelleri üzerinde 
durulmuş ve otel işletmelerinde çalışan yöneticilerin yaratıcılık engelleri belirlenmeye çalışılmıştır.

\section{YÖNTEM}

Yapılan bu araştırmanın amacı, otel işletmelerinde çalışan yöneticilerin yaratıcılıklarının önündeki engellerin belirlenmesidir. Lee ve diğerlerine (2019) göre şirket performansının önemli itici güçleri yaratıcılık ve yeniliktir. Günümüzde yaratıcılığa elverişli bir çalışma ortamı yaratan kurumlar kuşkusuz yaratıcılığı yüksek çalışanlarla rakipleriyle girdikleri rakabet yarışında öne geçmek için bir fırsat yakalamış olacaktır. Araştırma amacımız için kullanılan anket formu iki bölümden oluşmaktadır. Anketin birinci kısmında yöneticilerin demografik bilgilerini belirlemek amacıyla hazırlanmış 7 soru, anketin ikinci kısmında ise yöneticilerin yaratıcılık engellerini belirlemek amacıyla orjinal versiyonu Wong ve Pang (2003) tarafından hazırlanmış beşli likert tipinde (1: Kesinlikle Katılmıyorum, 5: Kesinlikle Katılıyorum) 17 ifade bulunmaktadır. Anketin orijinal halinde yer alan 17 ifade Türkçe' ye çevrilmiştir. Bu çeviri anadili Türkçe ve iyi düzeyde İngilizce bilen iki öğretim üyesi tarafından görüş alınarak gerekli düzeltmeler yapılmış daha sonra veri toplama aşamasına geçilmiştir. Hazırlanan anketler kolayda örnekleme yöntemi ile ulaşılabilen 110 kişi üzerinde uygulanmıştır. Ölçeğin güvenilirliğini test etmek amacıyla güvenilirlik (Cronbach's Alpha) değeri hesaplanmıştır. Cronbach's Alpha değerinin kabul edilebilir eşiğin üzerinde 0,922 olduğu tespit edilmiştir. Elde edilen tüm veriler İstatistik paket programında frekans analizi, ölçeğin alt boyutlarının belirlenebilmesi için faktör analizi, boyutlar arası ilişkilerin tespit edilmesi için korelasyon analizi, verilerin normal dağılıp dağılmadığını tespit etmek için Kolmogorov-Simirnov testi, veriler normal dağılıma uymadığı için değişkenler arasındaki farkların belirlenmesinde parametrik olmayan test yöntemlerinden mann-whitney $u$ testi ve kruskal-wallis testi kullanılarak analiz edilmiştir. Araştırmanın evrenini, Pamukkale Üniversitesi'nde 9 Mart 2020 tarihinde dördüncüsü gerçekleşen "Kariyer günleri"ne 43 otelden katılım gösteren 110 yönetici oluşturmaktadır. Evren olarak bu etkinliğe katılanların seçilmesinin sebebi sektörü temsil eden çok sayıda üst düzey yöneticinin ortak bir amaçla bir araya gelmiş olmasıdır. Etkinliğe toplam 110 yönetici katılmış ve katılımcıların hepsine 110 adet anket dağıtılmıştır. Etkinlik sonunda toplam 95 anket geri toplanmıştır. Anketlerden 5 adedi yanlış veya eksik doldurulduğu için iptal edilmiştir. Geçerli toplam anket sayısı 90 adettir. Örneklem büyüklüğünün hesaplanmasında ise Sekaran (1992)'nin önerdiği örneklem tablosundan yararlanılmıştır. Söz konusu tabloda, evren hacminin 110 olması halinde örneklem büyüklüğünün 86 olması gerektiği belirtilmiş olup araştırma kapsamına dahil edilen 90 kişi, araştırmamız için yeterlidir.

\section{BULGULAR}

Araştırmanın bu kısmında öncelikle elde edilen veriler sonucunda katılımcıların demografik özelliklerini belirlemek maksadıyla frekans değerleri analizi bulgularına yer verilmiştir. Tablo 1 'de görüldüğ ü üzere katılımcıların \%58'i erkek, \%42'si ise kadındır. Yaş dağılımı incelendiğinde ise, katılımcların \%34'ü 21-30 yaş grubunda, \%40'1 31-40 yaş grubunda, \%26'sı 41 ve üstü yaş grubundadır. Eğitim durumu incelendiğinde ise, katılımclların \%20'si lise düzeyinde, $\% 24^{\prime}$ ü önlisans düzeyinde, $\% 42$ 'si lisans düzeyinde ve $\% 13^{\prime}$ ü ise lisansüstü düzeydedir. Medeni durum incelendiğinde ise, katılımcıların \%47'si evli, \%52'si bekâr ve \%1'i ise boşanmıştır. Aylık gelir durumu incelendiğinde ise, katılımcıların \%20'si 2001-3000 TL aralığında gelire sahip, \%32'si 3001-4000 TL aralığında gelire sahip, \%24'ü 4001-5000 TL aralı̆̆ında gelire sahip, \%23'ü 5001 TL ve üzeri gelire sahiptir. Çalıştıkları departman incelendiğinde ise, katılımcıların \%4'ü 
rezervasyon, \%12'si önbüro, \%14'ü kat hizmetleri, \%20'si F\&B-Mutfak, \%40'ı insan kaynakları, \%1'i satış pazarlama, \%2'si güvenlik, \%3'ü yönetim, \%2'si muhasebe departmanında çalışmaktadır. Son olarak mevcut işyerlerinde çalışma süreleri incelendiğinde ise, katılımcıların \%14'ü 5 yıldan az, \%29'u 6-10 yıl arası, \%36'sı 11-15 yıl arası ve \%21'i 16 yıl ve üzeri süredir aynı işletmede çalışmaktadırlar. Elde edilen bulgular araştırmaya katılan erkek yöneticilerin kadın yöneticilerden sayıca daha fazla olduğunu, yaş olarak en fazla 31-40 yaş grubunda olduğunu, katılımcıların yarısından fazlasının lisans ve lisansüstü düzeyinde eğitim aldığını, bekâr yöneticilerin evli çalışanlardan sayıca daha fazla olduğunu, katılımcıların en fazla insan kaynakları departmanında çalıştıklarını, aylık gelir olarak en fazla 3001-4000 TL aralığında gelire sahip olduklarını ve son olarak katılımcıların \%86'sının 6 yıldan fazla süredir aynı işletmede çalıştıklarını göstermektedir.

Tablo 1. Katılımcıların Demografik Özelliklerine İlişkin Bulgular

\begin{tabular}{|c|c|c|c|}
\hline Değişkenler & Grup & $\mathrm{f}$ & $\%$ \\
\hline \multirow[b]{2}{*}{ Cinsiyet } & Kadın & 38 & 42 \\
\hline & Erkek & 52 & 58 \\
\hline \multirow{3}{*}{ Yaş } & $21-30$ & 31 & 34 \\
\hline & $31-40$ & 36 & 40 \\
\hline & 41 ve üstü & 23 & 26 \\
\hline \multirow{4}{*}{ Öğrenim Durumu } & Lise & 18 & 20 \\
\hline & Ön Lisans & 22 & 24 \\
\hline & Lisans & 38 & 42 \\
\hline & Lisans Üstü & 12 & 13 \\
\hline \multirow{3}{*}{ Medeni Durum } & Evli & 42 & 47 \\
\hline & Bekâr & 47 & 52 \\
\hline & Boşanmış & 1 & 1 \\
\hline \multirow{9}{*}{ Departman } & Rezervasyon & 4 & 4 \\
\hline & Önbüro & 11 & 12 \\
\hline & Kat Hizmetleri & 13 & 14 \\
\hline & F\&B - Mutfak & 18 & 20 \\
\hline & İnsan Kaynakları & 36 & 40 \\
\hline & Satış Pazarlama & 1 & 1 \\
\hline & Güvenlik & 2 & 2 \\
\hline & Yönetim & 3 & 3 \\
\hline & Muhasebe & 2 & 2 \\
\hline \multirow{4}{*}{ Aylık Gelir } & 2001 TL-3000 TL & 18 & 20 \\
\hline & 3001 TL-4000 TL & 29 & 32 \\
\hline & 4001 TL-5000 TL & 22 & 24 \\
\hline & 5001 TL ve üzeri & 21 & 23 \\
\hline \multirow{4}{*}{$\begin{array}{l}\text { Bu İş Yerindeki } \\
\text { Çalışma Süresi }\end{array}$} & 5 yıldan az & 13 & 14 \\
\hline & 6-10 yil & 26 & 29 \\
\hline & $11-15$ y1l & 32 & 36 \\
\hline & 16 yıl ve üzeri & 19 & 21 \\
\hline
\end{tabular}

Araştırmaya katılan 90 katılımcıdan toplanan verilere yapılan faktör analizinde ilk olarak ölçeğin geçerliliği ve faktör analizine uygunluğunu tespit etmek maksadıyla ön testler yapılmıştır. Tablo 2'de ölçeğe ilişkin KMO ve Barlett testi sonuçları bulunmaktadır. Ölçeğin, KMO testi sonucu $\% 86$ 'dır. Kaiser-Meyer-Olkin örneklem yeterlilik ölçüm kıstası 0 ile 1 arasında değer almaktadır. Bu değerin \%80 $(0,80)^{\prime}$ den büyük olması sebebiyle, araştırma örneklemi faktör analizi için 
yeterlidir (Dziuban ve Shirkey, 1974). Ayrıca, Bartlett testi değerinin $p<0,001$ olması değişkenler arasında anlamlı bir ilişkinin olduğunu göstermektedir.

Tablo 2. Otelcilikte Yaratıcılığın Önündeki Engeller Ölçeği KMO ve Bartlett Küresellik Testi Tablosu

\begin{tabular}{|l|l|l|}
\hline Kaiser-Meyer-Olkin Örneklem Yeterlilik Ölçümü & 0,858 \\
\hline \multirow{3}{*}{ Bartlett Küresellik Testi } & Yaklaş1k Ki-kare & 1042,987 \\
\cline { 2 - 3 } & Serbestlik derecesi & 105 \\
\cline { 2 - 3 } & Anlamlllık & 0,000 \\
\hline
\end{tabular}

Aşağıdaki Tablo 3'de otelcilikte yaratıcılığın önündeki engeller ölçeğinin faktör analizi sonuçlarına yer verilmiştir. Faktör analizinde değişkenlere ilişkin verilerin ortalamaları, faktör yükleri, öz değerleri ve açıklanan varyansları Tablo 3'de gösterilmektedir. Yapılan analiz sonucunda faktör yükleri düşük olarak tespit edilen "yaptığım iş takdir görmüyor." ve "riskli durumlardan kaçınıyorum." maddeleri ölçekten çıkarılmış ve analiz tekrarlanmıştır. Tekrarlanan yeni faktör analizine alınan maddelerin 15'inin özdeğeri 1'den büyük üç faktör altında toplandığ 1 görülmüştür. Yaratıcılığın önündeki engeller ölçeğinin 1. faktörü "Değişim korkusu, eleştiri, zaman ve iş baskısı" ile ilgili sekiz maddeden, 2. Faktörü "Örgüte ve sisteme düşük bağlllık" ile ilgili beş maddeden ve 3 . faktörü ise "Katı kurallar ve şirket tarzı" ile ilgili iki maddeden oluşmaktadır. Elde edilen üç faktör, toplam varyansın yaklaşık \%70,34'ünü açıklamaktadır. Önemli olarak belirlenen faktörlerden 1 . faktör, toplam varyansın $\% 39,62$ ' sini açılarken; 2 . faktör $\% 20,44$ 'ünü ve son olarak 3. faktör ise \%10,29'unu açıklamaktadır. Katılımcıların "değişim korkusu, eleştiri, zaman ve iş baskısı" ile ilgili maddelere verdikleri yanıtların ortalamalarının 2 (Katılmıyorum) ile 1 (Kesinlikle Katılmıyorum) değeri arasında yer aldığı sonucuna ulaşılmıştır. $\mathrm{Bu}$ sonuçtan hareketle, katılımcıların çalıştıkları kurumlarda çok fazla değişim korkusu yaşamadıkları, eleştiri almadıkları, zaman ve iş baskısına maruz kalmadıkları anlaşılmaktadır. Katılımcların "örgüte ve sisteme düşük bağlılık" ile ilgili maddelere verdikleri yanıtların ortalamalarını 2 (Katılmıyorum) ile 1 (Kesinlikle Katılmıyorum) değeri arasında yer aldığı sonucuna ulaşılmıştır. Bu sonuçtan hareketle, katılımcıların örgüte ve sisteme bağlılıklarının düşük olmadığı anlaşılmaktadır. Son olarak katılımcıların "katı kurallar ve şirket tarzı" ile ilgili maddelere verdikleri yanıtların ortalamalarının 2 (Katılmıyorum) ile 3 (kararsızım) değeri arasında yer aldığı sonucuna ulaşılmıştır. Bu sonuçtan hareketle, katılımcıların çalıştıkları kurumdaki kuralları ve şirket tarzını katı bulmadıkları anlaşılmaktadır. Genel bir değerlendirme yapılacak olursa, katılımcılarda çalıştıkları kurumlarda yaratıcılıklarının engellenmediği görüşü hâkimdir. Benzer şekilde Ertekin (2016) ve Kılınç (2018) de yaptıkları çalışmalarında çalışanların yönetsel yaratıcılık algılarının yüksek olduğunu, yönetsel açıdan yaratıcı bir ortamın çalışanlara sunulduğunu tespit ederken; Kendir (2013) ise üç, dört ve beş yıldızlı otel işletmelerinde çalışanlar üzerinde yaptığı çalışmasında ise yönetsel açıdan yaratıcı bir ortamın çalışanlara yöneticiler tarafından yeteri kadar sunulamadığını tespit etmiştir. Fisher ve Specht (1999), yöneticilerin örgütlerindeki yaratıcıllğı teşvik etmelerinin çalışanlar için oldukça önemli olduğunu vurgularken; Arköse, (2004) ise geleceğin örgütlerinin yaratıcı ve yenilikçi bir örgüt kültürüne sahip olanlar olduğunu vurgulamıştır. Günümüzde örgütler arasında kıyasıya bir rekabetin yaşanıldığı düşünüldüğünde yöneticilerin çalışanlara yaratıcılıklarını ortaya koyabilecekleri bir ortam sunmaları son derece önemlidir. Bu açıdan çalışmamızda katılımcıların yaratıcılıklarının engellenmediği görüşünün hâkim olması sektör için son derece olumlu bir bulgudur. 
Tablo 3. Otelcilikte Yaratıcılığın Önündeki Engeller Ölçeğine İlişkin Faktör Analizi Sonuçları

\begin{tabular}{|c|c|c|c|c|}
\hline Maddeler & Yük & Öz Değer & $\begin{array}{l}\text { Aç1klanan } \\
\text { Varyans \% }\end{array}$ & Ortalama \\
\hline $\begin{array}{l}\text { 1.Faktör: Değişim korkusu, eleştiri, zaman ve } \\
\text { iş baskısı }\end{array}$ & & 5,942 & 39,613 & 1,721 \\
\hline Başarısızlık korkum var. & 0,694 & & & 1,67 \\
\hline $\begin{array}{l}\text { Çalıştığım kurumda tehdite maruz } \\
\text { kalabiliyorum. }\end{array}$ & 0,826 & & & 1,58 \\
\hline Yıkıcı eleştirilere maruz kalıyorum. & 0,806 & & & 1,69 \\
\hline $\begin{array}{l}\text { Çalıştığım kurumda kalıplaşmış bir düşünce } \\
\text { biçimi söz konusu. }\end{array}$ & 0,800 & & & 1,87 \\
\hline Yönetim önerilerimi geri çeviriyor. & 0,859 & & & 1,82 \\
\hline Yönetim tarafından desteklenmiyorum. & 0,849 & & & 1,70 \\
\hline Zaman konusunda baskılanıyorum. & 0,779 & & & 1,74 \\
\hline Çalışma konusunda baskılanıyorum. & 0,852 & & & 1,70 \\
\hline 2.Faktör: Örgüte ve sisteme düşük bağlilık & & 3,066 & 20,439 & 1,820 \\
\hline $\begin{array}{l}\text { Kendimi çalıştığım kuruma dâhil } \\
\text { hissetmiyorum. }\end{array}$ & 0,840 & & & 1,71 \\
\hline Düşük moral ile çalışıyorum. & 0,671 & & & 1,73 \\
\hline $\begin{array}{l}\text { Çalıştığım kurumda iletişim eksikliği } \\
\text { olduğunu düşünüyorum. }\end{array}$ & 0,861 & & & 1,92 \\
\hline $\begin{array}{l}\text { Birbiriyle çatışan hedef ve amaçların } \\
\text { bulunduğunu düşünüyorum. }\end{array}$ & 0,621 & & & 2,15 \\
\hline $\begin{array}{l}\text { İş arkadaşlarımdan destek göremiyorum ve } \\
\text { uyumlu çalışamiyorum. }\end{array}$ & 0,466 & & & 1,58 \\
\hline 3.Faktör: Katı kurallar ve şirket tarzı & & 1,543 & 10,287 & 2,194 \\
\hline $\begin{array}{l}\text { Çalıştığım örgütte uyulması gereken katı } \\
\text { kurallar ve düzenlemeler var. }\end{array}$ & 0,834 & & & 2,20 \\
\hline $\begin{array}{l}\text { Çalıştı̆̆ım örgütte tutucu bir yönetim tarzı } \\
\text { var. }\end{array}$ & 0,840 & & & 2,18 \\
\hline
\end{tabular}

Faktör çıkarma metodu: Temel bileşenler analizi Döndürme metodu: Varimax

Açıklanan toplam varyans: \%70,339; Ölçeğin tamamı için güvenirlik katsayısı: 0,922

Yanıtlar: 1: Kesinlikle Katılmıyorum, 2: Katılmıyorum, 3: Kararsızım, 4: Katılıyorum, 5: Kesinlikle Katıliyorum

Aşağıdaki Tablo 4'de toplam ölçeğin ve alt boyutların Cronbach Alpha iç tutarlılık değerleri gösterilmiştir. Tablo incelendiğinde, toplam ölçeğin ve alt boyutların Cronbach Alpha iç tutarlılık değerleri, birinci alt boyut olan (Değişim korkusu, eleştiri, zaman ve iş baskısı için $\alpha=0,94$ ), ikinci alt boyut olan (Örgüte ve sisteme düşük bağlllık için $\alpha=0,84$ ) ve üçüncü alt boyut olan (Katı kurallar ve şirket tarzı için $\alpha=0,61$ ) olarak belirlenmiştir. Toplam ölçeğin Cronbach Alpha iç tutarlılık değeri ise $(\alpha=0,96)$ olarak bulunmuştur. Sipahi, Yurtkoru ve Çinko'ya (2008: 89) göre Cronbach Alpha değerinin 0,70 ve üzeri olması ölçeğin güvenilir olduğunun göstergesidir. Buradan hareketle, toplam ölçeğin ve alt boyutların güvenilir olduğunu söylemek mümkündür.

Aşağıdaki Tablo 5'de değişim korkusu, eleştiri, zaman ve iş baskısı, örgüte ve sisteme düşük bağlılık ve katı kurallar ve şirket tarzı boyutlarının aralarındaki ilişkiler incelenmiştir. Bu amaç doğrultusunda değişkenler arasındaki ilişkiyi saptamak için Pearson korelasyon analizi yapılmıştır. Korelasyon analizi sonuçlarına göre değişim korkusu, eleştiri, zaman ve iş baskısı ile örgüte ve sisteme düşük bağll1ık arasındaki ilişki incelendiğinde (Tablo 5), r=0,674 korelasyon değeri, pozitif yönlü ve orta düzeyde bir ilişkinin varlığını ve $p<0,01$ değeri ise korelasyonun yüksek derecede anlamlı olduğunu ifade etmektedir. Örgüte ve sisteme düşük bağlılık ile katı kurallar ve şirket tarzı arasındaki ilişki incelendiğinde (Tablo 5), r=0,211 korelasyon değeri, 
pozitif yönlü ve düşük düzeyde bir ilişkinin varlığını ve $p<0,05$ değeri ise korelasyonun anlamlı olduğunu ifade etmektedir. Değişim korkusu, eleştiri, zaman ve iş baskısı ile katı kurallar ve şirket tarzı değişkenleri arasında ise anlamlı bir ilişki tespit edilememiştir $(p>0,05)$.

Tablo 4. Otelcilikte Yaratıcılığın Önündeki Engeller Ölçeği alt boyutlarının ve toplam ölçeğin alfa değerleri

\begin{tabular}{|l|c|c|c|}
\hline \multicolumn{1}{|c|}{ Boyutlar } & Madde sayısı & $\begin{array}{c}\text { Alt boyutların } \\
\text { alfa değeri }\end{array}$ & $\begin{array}{c}\text { Toplam ölçeğin } \\
\text { alfa değeri }\end{array}$ \\
\cline { 1 - 3 } $\begin{array}{l}\text { Değişim korkusu, eleştiri, zaman ve iş } \\
\text { baskısı }\end{array}$ & 8 & 0,944 & \multirow{2}{*}{0,922} \\
\cline { 1 - 3 } Örgüte ve sisteme düşük bağllıı & 5 & 0,840 & \\
\cline { 1 - 3 } Katı kurallar ve şirket tarzı & 2 & 0,609 & \\
\hline
\end{tabular}

Tablo 5. Değişim Korkusu, Eleştiri, Zaman ve İş Baskısı, Örgüte ve Sisteme Düşük Bağlllık ve Katı Kurallar ve Şirket Tarzı Boyutlarının Birbirleri Arasındaki Basit Korelâsyon Katsayıları

\begin{tabular}{|c|l|c|c|c|}
\hline \multicolumn{2}{|c|}{ Boyutlar } & $\mathbf{1}$ & $\mathbf{2}$ & $\mathbf{3}$ \\
\hline 1 & Değişim korkusu, eleştiri, zaman ve iş baskısı & 1 & & \\
\hline 2 & Örgüte ve sisteme düşük bağllıı & $0,674^{* *}$ & 1 & \\
\hline 3 & Katı kurallar ve şirket tarzı & 0,140 & $0,211^{*}$ & 1 \\
\hline
\end{tabular}

* $\mathrm{p}<0,05$ anlamlılık düzeyinde ilişki anlamlı

${ }^{* *} \mathrm{p}<0,01$ anlamlılık düzeyinde ilişki anlamlı

Veri setinin normallik testi Kolmogorov-Simirnov ve Shapiro Wilk testleri aracillğıyla yapılmaktadır. Gözlem sayısı 29'dan fazla olduğunda Kolmogorov-Simirnov testi kullanılmaktadır (Kalaycı vd., 2008. 13). Araştırmamızda veri sayımız 90 olduğu için Kolmogorov-Simirnov testi sonucu incelenmiş olup, değişim korkusu, eleştiri, zaman ve iş baskısı, örgüte ve sisteme düşük bağlılık ve katı kurallar ve şirket tarzı verilerinin anlamlılık değeri 0,000 olarak tespit edilmiştir. Bu değerin 0,05'ten küçük olması sebebiyle verilerin normal dağılıma uymadığı tespit edilmiş ve bu sebeple değişkenler arasındaki farkların belirlenmesinde parametrik olmayan test yöntemlerinden Mann-Whitney U Testi ve Kruskal-Wallis Testi yöntemleri kullanılmıştır. Kolmogorov-Simirnov testi sonucu ilişkin değerler aşağıdaki Tablo $6^{\prime}$ da görülmektedir.

Tablo 6. Normallik Testi

\begin{tabular}{|l|c|c|c|}
\hline Değişkenler & $\mathbf{N}$ & $\begin{array}{c}\text { Kolmogorov-Smirnov Z } \\
\text { Değeri }\end{array}$ & $\mathbf{p}$ \\
\hline Değişim korkusu, eleştiri, zaman ve iş baskısı & 90 & 0,203 & 0,000 \\
\hline Örgüte ve sisteme düşük bağlılık & 90 & 0,188 & 0,000 \\
\hline Katı kurallar ve şirket tarzı & 90 & 0,188 & 0,000 \\
\hline
\end{tabular}

Araştırmanın bu bölümünde yöneticilerin demografik özellikleri (cinsiyet, yaş, eğitim düzeyi, iş yerindeki çalışma süresi, aylık gelir) ile yaratıcılığın engelleri (değişim korkusu, eleştiri, zaman ve iş baskısı, örgüte ve sisteme düşük bağlılık ve katı kurallar ve şirket tarzı) arasında istatistiksel olarak anlamlı farklılıklar olup olmadığı ile ilgili bilgiler farklılık analizleri (Mann-Whitney U Testi ve Kruskal-Wallis Testi yöntemleri) ile tespit edilmeye çalışılmıştır. Yaratıcılık engellerinin (değişim korkusu, eleştiri, zaman ve iş baskısı, örgüte ve sisteme düşük bağlılık ve katı kurallar 
ve şirket tarzı) yaş, eğitim durumu, iş yerindeki çalışma süresi ve aylık gelir değişkenlerine göre farklılaşıp farklılaşmadığını saptamak amacıyla yapılan Kruskal-Wallis testi sonuçları Tablo 7' de yer almaktadır. Medeni durum ve departmanın teste dahil edilmemesinin sebebi bazı değişken sayılarının yeterli olmamasıdır. Test sonucuna göre, değişim korkusu, eleştiri, zaman ve iş baskısı ile örgüte ve sisteme düşük bağlllık, yaş, eğitim durumu, iş yerindeki çalışma süresi ve aylık gelir değişkenlerine göre anlamlı bir farklılık göstermemektedir. Bu sebeple sonuçlara tabloda yer verilmemiştir. Benzer şekilde katı kurallar ve şirket tarzı ile yaş ve aylık gelir arasında anlamlı bir farklılık tespit edilemezken; eğitim $(\mathrm{p}=0,016<0,05)$ ve mevcut iş yerinde çalışma süresi $(\mathrm{p}=0,030<0,05)$ arasında ise anlamlı bir farklılık tespit edilmiştir.

Tablo 7. Katı Kurallar ve Şirket Tarzının Yaş, Eğitim Durumu, İş Yerindeki Çalışma Süresi ve Aylık Gelir Değişkenlerine Göre Farklılığını Gösteren Kruskal-Wallis Tablosu

\begin{tabular}{|c|c|c|c|c|c|}
\hline Değişken & $\mathbf{N}$ & $\begin{array}{c}\text { Sira } \\
\text { Ortalaması }\end{array}$ & Ki-Kare & $\begin{array}{l}\text { Serbestlik } \\
\text { Derecesi }\end{array}$ & $\mathbf{p}$ \\
\hline \multicolumn{6}{|c|}{ Yaş } \\
\hline $21-30$ & 31 & 46,65 & \multirow{3}{*}{0,473} & \multirow{3}{*}{2} & \multirow{3}{*}{0,789} \\
\hline $31-40$ & 36 & 46,53 & & & \\
\hline 41 ve üzeri & 23 & 42,35 & & & \\
\hline \multicolumn{6}{|c|}{ Aylık Gelir } \\
\hline $2001-3000$ & 18 & 45,33 & \multirow{5}{*}{0,015} & \multirow{5}{*}{3} & \multirow{5}{*}{1,000} \\
\hline $3001-4000$ & 29 & 45,52 & & & \\
\hline $4001-5000$ & 22 & 46,00 & & & \\
\hline 5001 ve üstü & 21 & 45,10 & & & \\
\hline Toplam & 90 & & & & \\
\hline \multicolumn{6}{|c|}{ Eğitim } \\
\hline Lise & 18 & 44,64 & \multirow{5}{*}{10,272} & \multirow{5}{*}{3} & \multirow{5}{*}{$0,016^{*}$} \\
\hline Ön lisans & 22 & 32,16 & & & \\
\hline Lisans & 38 & 49,38 & & & \\
\hline Lisans Üstü & 12 & 58,96 & & & \\
\hline Toplam & 90 & & & & \\
\hline \multicolumn{6}{|c|}{ Mevcut İş Yerinde Çalışma Süresi } \\
\hline 5 yıldan az & 13 & 57,42 & \multirow{5}{*}{8,983} & \multirow{5}{*}{3} & \multirow{5}{*}{$0,030^{*}$} \\
\hline 6-10 yıl arası & 26 & 43,75 & & & \\
\hline $11-15$ y1l arası & 32 & 36,81 & & & \\
\hline 16 yıl ve üstü & 19 & 54,37 & & & \\
\hline Toplam & 90 & & & & \\
\hline
\end{tabular}

Yukarıdaki Tablo 7'ye ait sonuçları sırasıyla daha detaylı değerlendirecek olursak; eğitime ilişkin olarak sonuçlar yöneticilerin eğitimleri ile katı kurallar ve şirket tarzı arasında anlamlı bir farklılık olduğunu göstermektedir. Benzer şekilde Kendir (2013)'de yaptığ çalışanların eğitimleri ile yönetsel yaratıclık algılarında anlamlı bir farklılık tespit etmiştir. Yapılan istatistikler katı kurallar ve şirket tarzını yaratıcılığın önündeki engel olarak gören en yüksek grubun lisansüstü eğitim düzeyindeki yöneticiler olduğunu göstermiştir. Lisansüstü düzeyde eğitim alan yöneticiler katı kurallar ve şirket tarzını lise, ön lisans ve lisans mezunu yöneticilere göre daha fazla yaratıcllı̆a engel olarak görmektedir.

Mevcut iş yerinde çalışma süresine ilişkin olarak sonuçlar yöneticilerin mevcut iş yerindeki çalışma süreleri ile katı kurallar ve şirket tarzı arasında anlamlı bir farklılık olduğunu göstermektedir. Benzer şekilde Kendir (2013)'de yaptığı çalışmada çalışanların mevcut iş yerindeki çalışma süreleri ile yönetsel yaratıcllık algılarında anlamlı bir farklılık tespit etmiştir. Yapılan istatistikler katı kurallar ve şirket tarzını yaratıcılığın önündeki engel olarak gören en yüksek grubun 5 yıldan az süredir mevcut işletmede çalışan yöneticiler olduğunu göstermiştir. 5 
yıldan az süredir mevcut işletmede çalışan yöneticiler katı kurallar ve şirket tarzını 6 yıldan daha fazla çalışan yöneticilere göre daha fazla yaratıcılığa engel olarak görmektedir. Benzer şekilde Ertekin (2016) da yaptığı çalışmasında katılımcıların çalışma yılları ile yönetsel yaratıcılık algılarında anlamlı bir farklılık olduğunu; 5 yıldan az süredir çalışanların yönetsel yaratıcılık algılarının 6 yıldan daha fazla çalışanlara kıyasla daha düşük olduğunu tespit etmiştir.

Mann-Whitney U Testi sonuçları dikkate alındığında; cinsiyet değişkenine göre değişim korkusu, eleştiri, zaman ve iş baskısı $(p=0,592>0,05)$ ile örgüte ve sisteme düşük bağlllık $(p=0,931>0,05)$ arasında anlamlı bir farklılık tespit edilmezken; katı kurallar ve şirket tarzı $(\mathrm{p}=0,016<0,05)$ arasında anlamlı bir farklılık tespit edilmiştir. Erkek yöneticilerin katı kurallar ve şirket tarzına ilişkin ortalaması kadın yöneticilerin katı kurallar ve şirket tarzına ilişkin ortalamasından daha yüksektir. Bu da bize erkek yöneticilerin, katı kurallar ve şirket tarzını kadın yöneticilere göre daha fazla yaratıcılığa engel olarak gördüğünü göstermektedir.

Tablo 4. Cinsiyet Değişkenine Göre Değişim Korkusu, Eleştiri, Zaman ve İş Baskısı, Örgüte ve Sisteme Düşük Bağlılık ve Katı Kurallar ve Şirket Tarzına İlişkin Mann-Whitney U Testi

\begin{tabular}{|c|c|c|c|c|c|c|}
\hline & Cinsiyet & $\mathbf{N}$ & $\begin{array}{c}\text { Sira } \\
\text { Ortalamas1 }\end{array}$ & $\begin{array}{l}\text { Siralama } \\
\text { Toplamı }\end{array}$ & $\begin{array}{c}\text { Mann } \\
\text { Whitney U }\end{array}$ & $\mathbf{p}$ \\
\hline \multirow{2}{*}{$\begin{array}{l}\text { Değişim korkusu, eleştiri, zaman ve iş } \\
\text { baskısı }\end{array}$} & Kadın & 38 & 43,79 & 1664,00 & \multirow{2}{*}{923,000} & \multirow{2}{*}{0,592} \\
\hline & Erkek & 52 & 46,75 & 2431,00 & & \\
\hline \multirow[t]{2}{*}{ Örgüte ve sisteme düşük bağlllık } & Kadın & 38 & 45,78 & 1739,50 & \multirow{2}{*}{977,500} & \multirow{2}{*}{0,931} \\
\hline & Erkek & 52 & 45,30 & 2355,50 & & \\
\hline \multirow[t]{2}{*}{ Katı kurallar ve şirket tarzı } & Kadin & 38 & 37,96 & 1442,50 & \multirow{2}{*}{701,500} & \multirow{2}{*}{$0,016^{*}$} \\
\hline & Erkek & 52 & 51,01 & 2652,50 & & \\
\hline
\end{tabular}

${ }^{*} \mathrm{p}<0,05$ anlamlılık düzeyinde ilişki anlamlı

\section{SONUÇ}

Elde edilen verilere faktör analizi uygulanmadan önce ilk olarak faktör analizine uygunluğunu tespit etmek maksadıyla KMO ve Barlett testleri yapılmıştır. Yapılan test sonucunda ölçeğin, KMO testi sonucu \%86 olarak tespit edilmiştir. Ayrıca, Bartlett testi değerinin $\mathrm{p}<0,001$ olması değişkenler arasında anlamlı bir ilişkinin olduğunu göstermektedir. Yapılan uygunluk testlerinin ardından faktör analizi yapılmıştır. Yapılan analiz sonucunda maddelerin $15^{\prime}$ inin özdeğeri 1'den büyük üç faktör altında toplandığı görülmüştür. Yaratıcilığın önündeki engeller ölçeğinin 1. faktörü "Değişim korkusu, eleştiri, zaman ve iş baskısı" ile ilgili sekiz maddeden, 2. Faktörü "Örgüte ve sisteme düşük bağlılık" ile ilgili beş maddeden ve 3. faktörü ise "Katı kurallar ve şirket tarzı" ile ilgili iki maddeden oluşmaktadır. Elde edilen üç faktör, toplam varyansın yaklaşık \%70,34'ünü açıklamaktadır. Katılımcıların "değişim korkusu, eleştiri, zaman ve iş baskısı" ile ilgili maddelere verdikleri yanıtların ortalamalarının 2 (Katılmıyorum) ile 1 (Kesinlikle Katılmıyorum) değeri arasında yer almasından, katılımcıların çalıştıkları kurumlarda çok fazla değişim korkusu yaşamadıkları, eleştiri almadıkları, zaman ve iş baskısına maruz kalmadıkları anlaşılmaktadır. Katılımcıların "örgüte ve sisteme düşük bağlılık" ile ilgili maddelere verdikleri yanıtların ortalamalarının 2 (Katılmıyorum) ile 1 (Kesinlikle Katılmıyorum) değeri arasında yer almasından, katılımcıların örgüte ve sisteme bağlılıklarının düşük olmadığı anlaşılmaktadır. Son olarak katılımcıların "katı kurallar ve şirket tarzı" ile ilgili maddelere verdikleri yanıtların ortalamalarını 2 (Katılmıyorum) ile 3 (kararsızım) değeri arasında yer almasından ise katılımcıların çalıştıkları kurumdaki kuralları ve şirket tarzını katı bulmadıkları anlaşılmaktadır. Genel bir değerlendirme yapılacak olursa, katılımcılarda çalıştıkları kurumlarda yaratıcılıklarının engellenmediği görüşü hâkimdir. 
Yaratıcllık engellerinin (değişim korkusu, eleştiri, zaman ve iş baskısı, örgüte ve sisteme düşük bağlılık ve katı kurallar ve şirket tarzı) yaş, eğitim durumu, iş yerindeki çalışma süresi ve aylık gelir değişkenlerine göre farklılaşıp farklılaşmadığını saptamak amacıyla yapılan Kruskal-Wallis testi sonucunda, değişim korkusu, eleştiri, zaman ve iş baskısı ile örgüte ve sisteme düşük bağlllık, yaş, eğitim durumu, iş yerindeki çalışma süresi ve aylık gelir değişkenlerine göre anlamlı bir farklılık göstermemektedir. Benzer şekilde katı kurallar ve şirket tarzı ile yaş ve aylık gelir arasında anlamlı bir farklılık tespit edilemezken; eğitim $(\mathrm{p}=0,016<0,05)$ ve mevcut iş yerinde çalışma süresi $(p=0,030<0,05)$ arasında ise anlamlı bir farklılık tespit edilmiştir. Eğitime ilişkin olarak sonuçlar, katı kurallar ve şirket tarzını yaratıcılığın önündeki engel olarak gören en yüksek grubun lisansüstü eğitim düzeyindeki yöneticiler olduğunu göstermiştir. Lisansüstü düzeyde eğitim alan yöneticiler katı kurallar ve şirket tarzını lise, ön lisans ve lisans mezunu yöneticilere göre daha fazla yaratıcılığa engel olarak görmektedir. Mevcut iş yerinde çalışma süresine ilişkin olarak sonuçlar, katı kurallar ve şirket tarzını yaratıcılığın önündeki engel olarak gören en yüksek grubun 5 yıldan az süredir mevcut işletmede çalışan yöneticiler olduğunu göstermiştir. 5 yıldan az süredir mevcut işletmede çalışan yöneticiler katı kurallar ve şirket tarzını 6 yıldan daha fazla çalışan yöneticilere göre daha fazla yaratıcılığa engel olarak görmektedir. Yaratıcılık engellerinin (değişim korkusu, eleştiri, zaman ve iş baskısı, örgüte ve sisteme düşük bağlılık ve katı kurallar ve şirket tarzı) cinsiyet değişkenine göre farklılaşıp farklılaşmadığını saptamak amacıyla yapılan Mann-Whitney U Testi sonucunda, erkek yöneticilerin, katı kurallar ve şirket tarzını $(p=0,016<0,05)$ kadın yöneticilere göre daha fazla yaratıcılığa engel olarak gördüğü tespit edilmiştir.

Kişinin kendisinden, iş vereninden ve iş ortamından kaynaklanan birçok durum yaratıcıllğ 1 engelleyebilmektedir. Yaratıcılı̆̆ 1 engeli olan durumların tespit edilmesi bu engellerin ortadan kaldırılabilmesinin ilk adımıdır. Yaratıcılığı engelleyen durumların tespit edilmesi bu engelleri oluşturan kişilerin davranışlarını değiştirmede, ya da iş ortamında değişikliğe gitmede etkili olabilmektedir.

Yaratıcı düşünce günümüzde artık neredeyse her çalışanda aranan bir özellik haline gelmiştir. Çalıştığı kurumlarda karşılaştıkları sorunlara yaratıcı çözümler üretebilen çalışanlar, çalıştıkları kurumlara önemli katkılar sağlamaktadırlar. Bu açıdan bakıldığında araştırmada çalışanların yaratıcılıklarının engellenmediği görüşünün hâkim olması olumlu bir sonuçtur. Çalışanlar yaratıcılıkları engellenmediğinde daha özgür düşünebilir, daha üretken olabilirler. Yaratıcilıklarını kullanabilecekleri ortamlarda çalışan, bu anlamda engellenmeyen çalışanlar daha yüksek motivasyonla çalışacak bu da dolaylı yoldan işletmenin verimliliğine katkı yaratacaktır. Örgüt içerisinde esnekliğin olmaması, katı kuralların hâkim olması ise tam tersi etki yaratarak çalışanların örgüte olan bağlılıklarını düşürecektir. Rekabetin günden güne arttığ günümüz dünyasında işletmeler için en önemli konulardan birisi de yaratıcı fikirdir. Yaratıcı fikirlerin oluşabilmesi için kuşkusuz uygun bir örgüt iklimi gereklidir. Bir örgütte çalışanlar arasında olumlu ilişkiler varsa, çalışanlar yöneticileri ile fikirlerini açıkça paylaşabiliyorsa, yaratıcılıkları engellenmiyorsa, çalışanlar kendilerini değerli hissedecek, daha yüksek bir motivasyon ve performans ile çalışacak ve örgüte olan bağlllıkları da artacaktır.

\section{KAYNAKÇA}

Agogué, M., Kazakçi, A., Hatchuel, A., Le Masson, P., Weil, B., Poirel, N., and Cassotti, M. (2014). The impact of type of examples on originality: Explaining fixation and stimulation effects. The Journal of Creative Behavior, 48(1), 1-12. 
Ahmadi, N. T., Mustaffa, S., and Ahmadi, A. (2014). The barriers of enhancing creativity developed by parents in developing countries. Procedia-Social and Behavioral Sciences, 114(21), 257-261.

Amabile, T., and Mueller, J. (2008). Studying creativity, its processes and its antecedents. An exploration of the componential theory of creativity. Teoksessa: Handbook of organizational creativity, toim. Shalley, CE-Zhou, J., 34-64.

Arköse, O. (2004). Yaratıcılığa ve Yeniliğe Yönlendirici Örgüt Yapısı. Yayınlanmış Yüksek Lisans Tezi. İzmir: Dokuz Eylül Üniversitesi Sosyal Bilimler Enstitüsü.

Azimi, S. (2012). Perspectives of teachers about impact of schools standard on their happiness. unpublished master's thesis. Tehran: Kharazmi Univercity.

Boz, N. ve Öztürk, H. M. (2020). Importance of Creativity and Innovation for Gastronomy and Business Tourism. In Accelerating Knowledge Sharing, Creativity, and Innovation Through Business Tourism. IGI Global.

Cardoso, C., and Badke-Schaub, P. E. T. R. A. (2011). The influence of different pictorial representations during idea generation. The Journal of Creative Behavior, 45(2), 130-146.

Davis, G. A. (1999). Barriers to creativity and creative attitudes. Encyclopedia of creativity, 1, 165-174.

De Stobbeleir, K. E., De Clippeleer, I., and Dewettinck, K. (2010). From creativity to success: Barriers and critical success factors in the creative process. Vlerick Leuven Gent Management School.

Dziuban, C. D. and Shirkey, E. C. (1974). When Is a Correletion Matrix Appropriate for Factor Analysis? Some Decision Rules. Psychological Bulletin, 81(6), 358-361.

El-Masry, A. A., and Mostafa, M. (2008). Perceived barriers to organizational creativity: a crosscultural study of British and Egyptian future marketing managers. Cross Cultural Management, 15(1), 81-93.

Ertekin, E. (2016). Seyahat Acentası Çalışanlarının Örgütsel Yaratıcılık ve Müşteri Memnuniyeti Algılamalarını Belirlemeye Yönelik Bir Araştırma, Yayınlanmamış Yüksek Lisans Tezi, Balıkesir Üniversitesi Sosyal Bilimler Enstitüsü, Balıkesir.

Fazelian, P. and Azimi, S. (2013). Creativity in Schools, World Conference on Psychology and Sociology, Procedia - Social and Behavioral Sciences. (82), 719- 723. doi: 10.1016/j.sbspro.2013.06.335

Fisher, Bradley and Specht, Diana (1999). Successful aging and creativity in later life. Journal of Aging Studies, 13(4), 457-472.

Foley, S. and Kazerounian, K. (2007, January). Barriers to Creativity in Engineering Education: A Study of Instructors and Students Perceptions. In ASME 2007 International Design Engineering Technical Conferences and Computers and Information in Engineering Conference (pp. 539-555). American Society of Mechanical Engineers Digital Collection.

Ghafarian Shirazi, H. R. (2014). Study of Creativity Barriers in Education, Indian J. Sci. Res, 6 (1) 55-60.

Gonçalves, M. (2017). Design finds a way: Creative strategies to cope with barriers to creativity. In DS 87-8 Proceedings of the 21st International Conference on Engineering Design (ICED 17) Vol 8: Human Behaviour in Design, Vancouver, Canada, 21-25.08. 2017 (pp. 569-578). 
Kalaycı, Şeref (2008), SPSS Uygulamalı Çok Değişkenli İstatistik Teknikleri. Ankara: Asil Yayın Dağıtım.

Kazerounian, K., and Foley, S. (2007). Barriers to creativity in engineering education: A study of instructors and students perceptions. Journal of Mechanical Design, Transactions of the ASME. Vol. 129,761-768.

Kendir, H. (2013). Konaklama İşletmelerinde Çalışan İşgörenlerin Örgütsel Yaratıcılık Algıları: Afyonkarahisar İli Örneği, Yayınlanmamış Yüksek Lisans Tezi, Gaziosmanpaşa Üniversitesi Sosyal Bilimler Enstitüsü, Tokat.

Khalilinezhad, S. E., Shahvarani, A. and Mardanbeigi, M. (2017). The analysis of the effect of removing barriers on the creativity of students' mathematical learning. Mathematics Education Trends and Research, 1, 1-11.

Kılınç, S. (2018). Psikolojik Sermaye ve İşgören Güçlendirmenin Örgütsel Yaratıcılık Üzerindeki Etkisi, Yayınlanmamış Doktora Tezi, Selçuk Üniversitesi Sosyal Bilimler Enstitüsü, Konya.

Lee, C., Hallak, R., and Sardeshmukh, S. R. (2019). Creativity and innovation in the restaurant sector: Supply-side processes and barriers to implementation. Tourism Management Perspectives, $31,54-62$.

McCrae, R. R., and Costa Jr, P. T. (1997). Conceptions and correlates of openness to experience. In Handbook of personality psychology (pp. 825-847). Academic Press.

Nordin, N., and Malik, M. (2015). Undergraduates' barriers to creative thought and innovative in a new millennial era. Procedia-Social and Behavioral Sciences, 201, 93-101.

Paulus, P. B. (2008). Fostering creativity in groups and teams. Handbook of organizational creativity, New York: Lawrence Erlbaum Associates. 165-188.

Popescu, M. I., Moraru, A., and Sava, N. I. (2015). Familial barriers in the development of creativity in preschoolers. Procedia-Social and Behavioral Sciences, 187, 601-606.

Rinkevich, J. L. (2011). Creative teaching: Why it matters and where to begin. The Clearing House: A Journal of Educational Strategies, Issues and Ideas, 84(5), 219-223.

Rosenbusch, N., Brinkmann, J., and Bausch, A. (2011). Is innovation always benefcial? A metaanalysis of the relationship between innovation and performance in SMEs. Journal of Business Venturing, 26, 441-457.

Samen, S. (2008). İşletmelerde yaratıcılığın önemi. Çukurova Üniversitesi Sosyal Bilimler Enstitüsü Dergisi,17(2), 363-378.

Sekaran, U. (1992). Research Methods for Business - A skill building approach. (2nd Ed). United States of America: John Wiley \& Sons, Inc.

Sipahi B., Yurtkoru, E.S. ve Çinko M. (2008). Sosyal Bilimlerde SPSS ile Veri Analizi, İstanbul: Beta Yayınları.

Sternberg, R. J. (2005). Manual de creativitate. Iaşi: Polirom, 17-37.

Tierney, P. (2008). Leadership and Employee Creativity, Handbook of Organizational Creativity New York: Lawrence Erlbaum Associates. 95-124.

Walter, C. (2012). Work environment barriers prohibiting creativity. Procedia-Social and Behavioral Sciences, 40, 642-648. 
West, M. A., and Richter, A. W. (2008). Climates and cultures for innovation and creativity at work. Handbook of organizational creativity, New York: Lawrence Erlbaum Associates. 211-236.

Wong, C. K. S. and Pang, W. L. L. (2003). Barriers to creativity in the hotel industry-perspectives of managers and supervisors. International Journal of Contemporary Hospitality Management, 15(1), 29-37. 